\title{
Are Real Assets Priced Internationally? Evidence from the Art Market
}

\author{
Kenneth Wieand \\ University of South Florida, U.S.A. \\ Jeff Donaldson \\ Northern Kentucky University, U.S.A. \\ Socorro Quintero \\ Oklahoma City University, U.S.A.
}

This article investigates the relationships between the U.S. and Japanese stock market indices and the prices of modern and impressionist paintings sold at auction in New York by Christies and Sotheby. An art price index is constructed to adjust for heterogeneity of individual paintings. Time series properties of the art price index are examined in relation with the S\&P500 and Topix stock market indices. The art-price index is heteroskedastic and autocorrelated. When the log-returns to art are compared to log-price returns to the S\&P500 and TOPIX stock indices, a single, common, long-term stochastic trend in the three indices is found. In the short run, log-changes of art prices are related to current and lagged log-changes of the TOPIX index only (JEL C22, G12, G15, L15).

Keywords: art prices, cointegration, GARCH model, hedonic price equation, S\&P500 stock index, and TOPIX stock index.

\section{Introduction}

The question of what determines art prices is an intriguing one. It is commonly argued that art patrons do not view art as an investment. One

*The authors would like to acknowledge Professors Rob Weigand and Engin Kucukkaya and the editors of the journal for their assistance on this paper.

(Multinational Finance Journal, 1998, vol. 2, no. 3, pp. 167-187)

(C)Multinational Finance Society, a nonprofit corporation. All rights reserved. DOI: $10.17578 / 2-3-1$ 
also hears that art serves primarily as a hedge against inflation. Interestingly, many active participants in the art market are of the opinion that art prices follow the behavior of the stock market. In an article written in Barrons by Mahar (1987) during the art boom in the late 1980s, Christopher Burge, president of the American branch of Christies auction house, drew a parallel with the early 1970s:

"In 1973, things got very heated. There was a lot of money around. Foreign currencies were strong. The Italians and Swiss were buying. The Japanese were buying impressionists. Then the stock market fell, and we got all those people fleeing the stock market for a very dangerous five or six months, looking for a hedge. Then the oil crisis hit, the Japanese disappeared, and the pit props were knocked out from under our market."

In the same article, David Nash, director of fine arts for Sotheby's auction house, attributed the buying boom to the entrance of Japanese investors in the market.

"Today the Japanese are also the big spenders boosting impressionist paintings. And at any auction, it takes only two Japanese-a top bidder and an underbidder-to create levels well above the underlying market. ...Nash estimates that the Japanese make up roughly a third of the buyers in this field. If the stock market in Japan collapses, causing Japanese investors to repatriate the money, the false bottom could drop out of that top-drawer art market."

Comparison of the merits of these contrasting views is difficult because little statistical evidence exists linking the behavior of art prices over time to stock prices or other factors.

The purpose of this article is to examine the impact of U.S. and Japanese equity markets on art prices. For this purpose, an art price index, adjusted for heterogeneity, is used. The index is constructed from a sample of impressionist and modern paintings sold at auctions held by Sotheby and Christies in New York using a hedonic price equation.

Section II presents some of the issues involved in estimating returns to art and art price indices and provides a short review of the existing literature on the subject. Section III discusses the sample, the variables, 
and the empirical methodology used to estimate the art price index. Also, it provides some preliminary statistics on the art price, the U.S., and the Japanese stock indices. Section IV presents the main empirical findings. Summary and conclusions are presented in section V.

\section{Estimation of Art Prices and Findings}

Art differs from financial assets, which usually generate periodic cash flows. For most art owners, implicit rents to ownership accrue from the aesthetic benefits of possession and from the status derived from ownership and possession. The cash equivalents of these benefits are not measurable. Nor are the cost figures for storage and maintenance, which are important components of cash flows, readily accessible. ${ }^{1}$ For these reasons, although existing work on the investment performance of art often reports results in terms of the total returns to art, extant measures of returns to art are limited to measures of price appreciation. All references to art returns below refer only to measures of returns in terms of price appreciation.

The market in impressionist and modern paintings is maintained by two competing auction houses that report art-price transactions for a large number of paintings. A problem encountered in measuring prices stems from the fact that not all paintings are traded at auction. Paintings at the low end of the market tend not to be traded, and many valuable paintings, once acquired by museums, are not traded. Returns based upon auction prices thus suffer from selection bias at both the low and the high ends of the market. Moreover, paintings are less liquid than common stock, because art auctions are held infrequently, and because sellers and buyers incur large transaction costs. ${ }^{2}$

A conceptually more fundamental problem in measuring prices is heterogeneity of art. The ability of the market to set efficiently expected rates of return on objects of art depends upon whether art investors are able to find a way to pierce the veil of heterogeneity and to evaluate the

1. Owners may lend paintings for a fee to compensate them for the loss of possession. Data on these fees are, however, not readily available.

2. Christies and Sotheby's conduct most auctions of impressionist and modern art in the months of February, May, and November. 
TABLE 1. Past Empirical Findings on Art Price Returns

\begin{tabular}{|c|c|c|c|c|c|}
\hline Article & Period & Mean & St. Dev. & Beta & Correlation \\
\hline Baumol (1986) & $1652-1961$ & & & $\begin{array}{l}1.25 \\
(2.40)^{*}\end{array}$ & \\
\hline $\begin{array}{l}\text { Frey and Pommerehne } \\
\text { (1989) }\end{array}$ & $\begin{array}{l}1635-1987 \\
1950-1987\end{array}$ & $\begin{array}{l}1.80 \\
6.70\end{array}$ & & $\begin{array}{l}5.0 \\
4.7\end{array}$ & \\
\hline Goetzmann (1993) & $\begin{array}{l}1716-1986 \\
1900-1986\end{array}$ & $\begin{array}{r}3.20 \\
17.50\end{array}$ & $\begin{array}{l}56.50 \\
52.80\end{array}$ & & .67 \\
\hline $\begin{array}{l}\text { Mastumo, Andoh, } \\
\text { and Hoban (1994 }\end{array}$ & 1975-1989 & 16.00 & 17.00 & & \\
\hline Pesando (1993) & 1977-1992 & 1.51 & 19.90 & $\begin{array}{c}.31 \\
(1.84)\end{array}$ & .30 \\
\hline Stein (1977) & & 10.47 & & $\begin{array}{c}.82 \\
(2.40)^{*}\end{array}$ & \\
\hline
\end{tabular}

Note: Statistics are for annual returns expressed as percentages. St. Dev. is for the standard deviation. Beta is the market beta of art returns. Correlation is the correlation between art and stock market returns. Parentheses include the t-values for the estimates. *Statistically significant at the five-percent level.

investment performance of individual works of art, such as paintings and sculptures, in relation to each other and to other assets, e.g., Baumol (1986).

One method of estimating returns of heterogeneous paintings is to construct price indices of fixed collections of art works that are periodically appraised by experts, e.g., Matsumoto, Andoh, and Hoban (1994). Another method is to use resales of art to construct a time series of market values from which rates of price increase are calculated, e.g., Pesando (1993) and Goetzmann (1993). The hedonic price estimation method used to construct the art-price index in this article adjusts paintings for their individual characteristics and uses the adjusted prices to construct a time series of art prices.

Table 1 summarizes the findings on art prices of several published articles based on different data and time periods. The findings are quite diverse, but general conclusions can be summarized as follows:

1. The returns to art, as measured solely by price changes, are lower 
than returns to other assets. Returns in the past 50 years, however, are greater than those realized over longer periods. These higher returns occurred during periods of accelerated inflation rates. The latter may be due to wealth holders using that art as an inflation hedge.

2. Standard deviations of art returns are large relative to other assets. For example, Goetzmann (1993) finds the annual standard deviations of returns for paintings to be $56.5 \%$, which is roughly three times that of major world stock market indices.

3. There is evidence that the returns for paintings are positively correlated with stock-price index returns. Goetzmann (1993) finds the correlation between stock index returns and paintings returns to be .67 and Pesando (1993) to be .30. Moreover, beta estimates for art returns range from .32 to over 1 .

\section{Estimation of Art Prices}

\section{A. Sample and Variables}

The sample includes 5,898 transactions of impressionist and modern paintings sold at 147 auctions during the period May 1977 to May 1995. Most of these auctions took place in November, February, and May. The paintings represent the work of 236 artists. The average number of days between auctions is 55. Auction prices of paintings in the sample range from $\$ 2,750$ to $\$ 82.5$ million. Data on various attributes for these paintings are collected from the auction catalogs printed by Sotheby and Christies in New York. ${ }^{3}$

Table 2 provides a list of potential explanatory variables for the hedonic price equation of art paintings. The dummy variables for the months of November (Nov), February (Feb), and May (May) are constructed to examine whether the month of sale influences average sale prices of paintings. The dummy variable for paintings sold during the second or third day of a multi-day auction or on a Monday following a Friday's auction (Samauc) is intended to account for influences (spillovers) from the first day's sales. Dummy variables are also

3. Prices of paintings sold at auction are reported in addenda inserted in the catalogs. 
TABLE 2. Attribute Variables Considered in the Hedonic Price Equation

\begin{tabular}{|c|c|}
\hline Animal & 1 for plant or animal paintings \\
\hline Artistj & 1 for artist $j$ and 0 otherwise; $j=1,2, \ldots, 236$ \\
\hline Attrib & 1 for paintings attributed to an artist \\
\hline Base1 & 1 if the base includes panel, board, or stretcher \\
\hline Base2 & 1 if the base includes masonite or burlap \\
\hline Bears & 1 for paintings reported as bears signature \\
\hline Bearsdate & 1 for paintings reported as bears date \\
\hline Bldgs & 1 if the painting is a cityscape or has buildings prominently displayed \\
\hline Canvas & 1 for paintings on canvas \\
\hline Circa & 1 for paintings reported as painted circa \\
\hline Collage & 1 if the work was a collage (used detempe, enamel, or vinyl) \\
\hline Crayon & 1 if the media included crayons, chalk, charcoal, or pencil \\
\hline Dated & 1 for dated paintings or for paintings reported as painted in \\
\hline Execin & 1 for paintings reported as executed in ... \\
\hline Exhibits & Number of times the painting was exhibited \\
\hline $\mathrm{Feb}$ & 1 for auctions held in February \\
\hline Galleries & Number of reported gallery owners \\
\hline Geometric & 1 for painting with lines, irregular colors, and geometric shape(s) \\
\hline Gouache & 1 if media include gouache, paste, or gesso \\
\hline History & 1 for historical theme paintings \\
\hline House & 1 for Sotheby and 0 for Christies \\
\hline Initials & 1 for paintings bearing the artist's initials \\
\hline Inscript & 1 for paintings bearing an inscription by the artist \\
\hline Landscape & 1 for rural landscape paintings \\
\hline Literature & Number of reported treatments in the literature \\
\hline May & 1 for auctions held in May \\
\hline Monogram & 1 for paintings bearing a monogram of the artist's name \\
\hline Mowners & Number of reported museums-owners \\
\hline Museums & Number of times the painting was exhibited in museums \\
\hline Nodate & 1 for paintings with no date information \\
\hline Nov & 1 for auctions held in November \\
\hline Objects & 1 for paintings including object(s) \\
\hline Oil & 1 for paintings painted in oil \\
\hline Owners & Number of reported owners \\
\hline Other1 & 1 if media include chalk, charcoal, crayons, pencil, or enamel \\
\hline Other2 & 1 if media include sand, plaster brush, vinyl, or detempe \\
\hline Paper & 1 for paintings on paper \\
\hline Pen & 1 for paintings done in pen \\
\hline Person & 1 for paintings with one-person study \\
\hline Portrait & 1 for portrait paintings \\
\hline Religious & 1 for religious-theme paintings \\
\hline Samauc & $\begin{array}{l}1 \text { for consecutive days of a multi-day auction or for a Monday auction } \\
\text { following a Friday auction. }\end{array}$ \\
\hline Seascape & 1 for seascape paintings \\
\hline Signed & 1 for signed paintings (and 0 otherwise) \\
\hline Size & Size of the painting measured in square feet \\
\hline Size2 & Size squared \\
\hline Stamp & 1 for paintings bearing a stamp of the artist's name \\
\hline Water & 1 for paintings painted in watercolors \\
\hline
\end{tabular}


introduced for each of the 236 artists represented in the sample (Artistj), the materials used, the auction house, subject matter of the painting, the date and signature, and information on the painting's history, including ownership, number of public exhibitions, number of owners, and discussions of the painting in the art literature.

\section{B. Hedonic Pricing Model for Art Works}

The prices of individual paintings depend on a common set of observable physical, historical, and other attributes. Each attribute contributes to the overall price of the painting. Let $P_{i, t}$ be the price of painting $i$ sold at time $t$ and $X_{i}=\left[X_{i, 1}, X_{i, 2}, \ldots, X_{i, n}\right]$ be an attribute vector. For example, $X_{i, 1}$ may represent the size of the painting in square inches; i.e., for a painting of one square foot, $X_{i, 1}=144$.

The art-price equation is estimated using a semi-log specification for the price of each painting. This specification is often employed in price equations because of its flexibility in capturing nonlinear relationships between price and the various commodity attributes. The estimated regression model is

$$
\ln P_{i, t}=\hat{\alpha}+\hat{\beta} X_{i}+\hat{\varepsilon}_{i, t},
$$

for $i=1,2, \ldots, N$, where $N$ represents the number of individual paintings (transactions) in the sample, $\hat{\alpha}$ is the intercept of the price equation, $\hat{\beta}$ is a vector of slope coefficients corresponding to each variable in $X_{i}$, and $\hat{\varepsilon}_{i, t}$ is the regression residual. Note that the first component of equation 1 provides an estimate for the (hedonic) price of painting $i$ based on its attribute vector $X_{i}$, i.e.,

$$
\ln \hat{P}_{i}=\hat{\alpha}+\hat{\beta} X_{i}
$$

The regression residuals

$$
\hat{\varepsilon}_{i, t}=\ln P_{i, t}-\ln \hat{P}_{i, t}=\ln \left(P_{i, t} / \hat{P}_{i}\right)
$$


have a zero mean in the overall sample and they are orthogonal (uncorrelated) with the attribute vector $X_{i}$. Nevertheless, they retain the time-series properties of the prices of individual paintings.

Let $N_{t}$ denote the number of paintings auctioned during period $t$. The mean of the residuals for period $t$, which may not be zero, is

$$
\ln V_{t} \equiv \frac{1}{N_{t}} \sum_{i=1}^{N_{t}} \hat{\varepsilon}_{i, t}=\frac{1}{N_{t}} \sum_{i=1}^{N_{t}} \ln \frac{P_{i, t}}{\hat{P}_{i}}
$$

The measure $V_{t}$ is an aggregate index for the prices of paintings sold during period $t$ adjusted for heterogeneity. As such, $V_{t}$ provides an estimate of the behavior over time of the average value of paintings independent of the attributes of individual paintings sold on each auction date. It can be easily shown that $V_{t}$ is equal to the geometric average of the relative prices of all paintings sold during period $t$, $P_{i, t} / \hat{P}_{i} \cdot{ }^{4} V_{t}$ is well-suited for time series analysis. Its reliance upon actual market transactions is an advantage over indices that are based upon appraised values. ${ }^{5}$ The distribution of $\ln V_{t}$ is expected to be similar to those of stock market indices. This allows the use of standard regression techniques to estimate stock price-art-price relationships over a relatively short period of time.

An additional advantage of the above approach is that the constructed price series $V_{t}$ is consistent with the manner in which auction house as well as art investors use historical prices to learn about the behavior of returns to art over time. Specifically, auction houses and investors (buyers) hire art experts to prepare estimates of the selling prices of paintings to be auctioned. These experts evaluate the merits of each painting to be auctioned on a basis of attributes such as its physical and aesthetic characteristics.

4. $V_{t}=\exp \left(\frac{1}{N_{t}} \sum_{i=1}^{N_{t}} \ln \frac{P_{i, t}}{\hat{P}_{i}}\right)=\exp \left(\frac{1}{N_{t}} \ln \prod_{i=1}^{N_{t}} \frac{P_{i, t}}{\hat{P}_{i}}\right)=\left(\prod_{i=1}^{N_{t}} \frac{P_{i, t}}{\hat{P}_{i}}\right)^{\frac{1}{N_{t}}}$

5. Appraisals are known to smooth actual fluctuations in asset prices and are likely to yield biased measures of total and systematic risk. 
Price estimates based on equation 1 are, however, useful only to the extent that the underlying functional form relating the prices and attributes of individual paintings is correct and the regression explains a large portion of the variance of prices.

\section{Estimation of the Hedonic Pricing Model}

The regression model in (1) is estimated using OLS. Table 3 presents the estimated regression coefficients for painting characteristics and artists that have a significant impact on art prices. The equation explains 60 percent of the variance in art prices independent of the temporal changes in art prices. The ten most important explanatory variables, in decreasing F-value sequence, are Exhibits, Owners, Feb, Oil, Literature, Size, Size2, House, Nov, and May. Together they explain 40 percent of the variance. The variables Exhibits, Owners, and Literature contain information about the painting's history and reveal information about critical appraisal of the painting. Feb, Nov, and May show that paintings sell for a discount in the month of February, and for a premium in the months of November and May. Oil, Size, and Size2 represent physical characteristics of the paintings. The variable House indicates that, ceteris paribus, Christies auction prices are higher than Sotheby's. The results in table 3 indicate that the subject matter of a painting has little influence on the market value of art, and that signed and dated paintings command a premium. Traditional canvas surface also commands a premium. According to the art-price equation, the price of an average (typical)-sized painting painted in oil on canvas, dated and signed with an average provenance and an artist coefficient of zero, is $\exp (3.83)=\$ 46,040 .^{6}$

Of the 236 artists in the sample, 54 have a statistically significant impact on art prices at a 5\% level of confidence. The significance of an artist depends upon the number of paintings traded and upon the size of the premium or discount associated with the artist's paintings. Panel B of table 3 reports the coefficients for individual artists that have significant coefficients in the art price equation. For example, a typical painting painted by Van Gogh, who has a coefficient of 2.6855, is

6. The mean value for the regression equation 1 is $\overline{\ln \hat{P}_{i}}=\hat{\alpha}+\hat{\beta} \bar{X}_{i}=3.83$, where $\bar{X}_{i}$ is the mean of the explanatory variables in the sample. 
TABLE 3. Hedonic Pricing Model for Art Prices

\begin{tabular}{|c|c|c|c|c|c|c|c|c|c|}
\hline \multicolumn{10}{|c|}{ A. Art attributes } \\
\hline Intercept & $\begin{array}{c}1.8407 \\
(2.58)^{*}\end{array}$ & Collage & $\begin{array}{l}-.0209 \\
(-.12)\end{array}$ & May & $\begin{array}{r}.3518 \\
(6.77)^{*}\end{array}$ & Person & $\begin{array}{c}-.1539 \\
(-1.20)\end{array}$ & Literature & $\begin{array}{r}.0767 \\
(10.5)^{*}\end{array}$ \\
\hline Geometric & $\begin{array}{l}-.2380 \\
(-1.81)\end{array}$ & Crayon & $\begin{array}{c}-.2562 \\
(-4.62)^{*}\end{array}$ & Nov & $\begin{array}{r}.4246 \\
(7.91)^{*}\end{array}$ & Portrait & $\begin{array}{c}-.1743 \\
(-1.30)\end{array}$ & Museums & $\begin{array}{c}.0340 \\
(1.86)\end{array}$ \\
\hline Animal & $\begin{array}{c}-.2296 \\
(-1.74)\end{array}$ & Execin & $\begin{array}{r}-.1837 \\
(-2.96)^{*}\end{array}$ & Samauc & $\begin{array}{r}-.0742 \\
(-2.33)^{*}\end{array}$ & Religious & $\begin{array}{l}.0288 \\
(.14)\end{array}$ & Mowners & $\begin{array}{r}.0592 \\
(2.88)^{*}\end{array}$ \\
\hline Attrib & $\begin{array}{l}.1616 \\
(.39)\end{array}$ & $\mathrm{Feb}$ & $\begin{array}{c}-.2732 \\
(-4.83)^{*}\end{array}$ & Monogram & $\begin{array}{l}-.0476 \\
(-.29)\end{array}$ & Seascape & $\begin{array}{c}-.3331 \\
(-2.39)^{*}\end{array}$ & Owners & $\begin{array}{r}.0915 \\
(8.71)^{*}\end{array}$ \\
\hline Base 1 & $\begin{array}{c}.0892 \\
(1.80)\end{array}$ & Gouache & $\begin{array}{c}.1572 \\
(2.71)^{*}\end{array}$ & Objects & $\begin{array}{r}-.3654 \\
(-2.73)^{*}\end{array}$ & Signed & $\begin{array}{r}.2295 \\
(3.60)^{*}\end{array}$ & Samauc & $\begin{array}{r}-.0742 \\
(-2.33)^{*}\end{array}$ \\
\hline Bears & $\begin{array}{l}.3951 \\
(1.44)\end{array}$ & House & $\begin{array}{r}-.1667 \\
(-5.67)^{*}\end{array}$ & Oil & $\begin{array}{r}.4981 \\
(6.67)^{*}\end{array}$ & Stamp & $\begin{array}{l}-.0644 \\
(-.70)\end{array}$ & Size & $\begin{array}{l}.1051 \\
(19.5)^{*}\end{array}$ \\
\hline Bldgs & $\begin{array}{c}-.2844 \\
(-2.18)^{*}\end{array}$ & Initials & $\begin{array}{l}-.1288 \\
(-1.41)\end{array}$ & Dated & $\begin{array}{c}.1143 \\
(3.37)^{*}\end{array}$ & Water & $\begin{array}{l}.0018 \\
(.03)\end{array}$ & Size2 & $\begin{array}{c}.0013 \\
(14.6)^{*}\end{array}$ \\
\hline Canvas & $\begin{array}{c}.1756 \\
(2.93)^{*}\end{array}$ & Inscript & $\begin{array}{c}-.1708 \\
(-2.87)^{*}\end{array}$ & Paper & $\begin{array}{c}-.0932 \\
(-1.63)\end{array}$ & Exhibits & $\begin{array}{r}.0720 \\
(7.36)^{*}\end{array}$ & $F$-Value & 31.19 \\
\hline Circa & $\begin{array}{r}-.1792 \\
(-4.30)^{*}\end{array}$ & Landscape & $\begin{array}{r}-.3227 \\
(-2.50)^{*}\end{array}$ & Pen & $\begin{array}{l}.0044 \\
(.07)\end{array}$ & Galleries & $\begin{array}{r}.1109 \\
(3.88)^{*}\end{array}$ & $\begin{array}{l}R-\text { Square } \\
N O B S\end{array}$ & $5898^{.61}$ \\
\hline
\end{tabular}

(Continued) 
TABLE 3. (Continued)

\begin{tabular}{|c|c|c|c|c|c|c|c|c|c|}
\hline \multicolumn{10}{|c|}{ B. Coefficients for individual artists } \\
\hline Bonnard & $\begin{array}{c}1.7605 \\
(2.94)^{*}\end{array}$ & Foujita & $\begin{array}{l}1.8710 \\
(2.65)^{*}\end{array}$ & Leger & $\begin{array}{c}1.6710 \\
(2.38)^{*}\end{array}$ & Mueller & $\begin{array}{c}2.1927 \\
(2.66)^{*}\end{array}$ & Seligman & $\begin{array}{l}-1.7887 \\
(-2.10)^{*}\end{array}$ \\
\hline Braque & $\begin{array}{l}1.8703 \\
(2.63)^{*}\end{array}$ & Gauguin & $\begin{array}{l}1.9000 \\
(2.64)^{*}\end{array}$ & Levy & $\begin{array}{l}-2.5085 \\
(-2.09)^{*}\end{array}$ & Munch & $\begin{array}{l}1.5546 \\
(2.04)^{*}\end{array}$ & Seurat & $\begin{array}{c}2.2539 \\
(2.63)^{*}\end{array}$ \\
\hline Caillebotte & $\begin{array}{c}1.9633 \\
(2.62)^{*}\end{array}$ & Giacommeti & $\begin{array}{c}2.0167 \\
(2.75)^{*}\end{array}$ & Magritte & $\begin{array}{c}1.7346 \\
(2.45)^{*}\end{array}$ & Nolde & $\begin{array}{c}1.5023 \\
(2.08)^{*}\end{array}$ & Signac & $\begin{array}{c}1.4368 \\
(2.03)^{*}\end{array}$ \\
\hline Cassatt & $\begin{array}{c}2.9163 \\
(4.00)^{*}\end{array}$ & Gris & $\begin{array}{l}1.4678 \\
(2.01)^{*}\end{array}$ & Manet & $\begin{array}{c}1.8967 \\
(2.57)^{*}\end{array}$ & Oguiss & $\begin{array}{c}2.0799 \\
(2.12)^{*}\end{array}$ & Sisley & $\begin{array}{c}2.2324 \\
(3.15)^{*}\end{array}$ \\
\hline Cezanne & $\begin{array}{r}2.6229 \\
(3.65)^{*}\end{array}$ & Gonzales & $\begin{array}{c}2.8481 \\
(2.89)^{*}\end{array}$ & Matisse & $\begin{array}{r}2.3097 \\
(3.27)^{*}\end{array}$ & Picasso & $\begin{array}{c}2.2023 \\
(3.15)^{*}\end{array}$ & Stael & $\begin{array}{r}1.5037 \\
(1.97)^{*}\end{array}$ \\
\hline Chagall & $\begin{array}{c}2.3703 \\
(3.37)^{*}\end{array}$ & Jawlensky & $\begin{array}{c}1.5743 \\
(2.19)^{*}\end{array}$ & Millet & $\begin{array}{c}2.3956 \\
(1.99)^{*}\end{array}$ & Pissaro & $\begin{array}{c}2.0468 \\
(2.91)^{*}\end{array}$ & Tanguy & $\begin{array}{c}1.5391 \\
(2.08)^{*}\end{array}$ \\
\hline Chirico & $\begin{array}{c}1.4447 \\
(2.02)^{*}\end{array}$ & Kandinsky & $\begin{array}{l}2.1295 \\
(2.97)^{*}\end{array}$ & Miro & $\begin{array}{c}1.7691 \\
(2.52)^{*}\end{array}$ & Redon & $\begin{array}{c}1.8438 \\
(2.59)^{*}\end{array}$ & $\begin{array}{l}\text { Toulouse- } \\
\text { Latrec }\end{array}$ & $\begin{array}{c}1.9882 \\
(2.77)^{*}\end{array}$ \\
\hline Courbet & $\begin{array}{c}1.5710 \\
(1.99)^{*}\end{array}$ & Klimt & $\begin{array}{c}2.5073 \\
(2.55)^{*}\end{array}$ & Modigliani & $\begin{array}{c}2.4182 \\
(3.36)^{*}\end{array}$ & Renoir & $\begin{array}{c}2.2901 \\
(3.27)^{*}\end{array}$ & Utrillo & 1.3724 \\
\hline Dali & $\begin{array}{c}1.6361 \\
(2.30)^{*}\end{array}$ & Klossosky & $\begin{array}{c}1.7949 \\
(2.54)^{*}\end{array}$ & Mondrian & $\begin{array}{c}1.4523 \\
(1.98)^{*}\end{array}$ & Roualt & $\begin{array}{c}1.4836 \\
(2.10)^{*}\end{array}$ & Van Gogh & $\begin{array}{l}(1.95)^{*} \\
2.6855\end{array}$ \\
\hline Degas & $\begin{array}{c}2.8010 \\
(3.96)^{*}\end{array}$ & Klee & $\begin{array}{l}2.8615 \\
(2.38)^{*}\end{array}$ & Monet & $\begin{array}{c}2.3600 \\
(3.36)^{*}\end{array}$ & Schiele & $\begin{array}{c}2.0048 \\
(2.76)^{*}\end{array}$ & Vuillard & $\begin{array}{r}(3.69)^{*} \\
1.3765\end{array}$ \\
\hline $\begin{array}{l}\text { Fantin- } \\
\text { Latour }\end{array}$ & $\begin{array}{c}1.6754 \\
(2.35)^{*}\end{array}$ & Laurencin & $\begin{array}{c}1.4894 \\
(2.11)^{*}\end{array}$ & Morandi & $\begin{array}{c}1.8800 \\
(2.55)^{*}\end{array}$ & Schwitters & $\begin{array}{c}1.6279 \\
(2.15)^{*}\end{array}$ & & $(1.95)^{*}$ \\
\hline
\end{tabular}

Note: Parentheses include the t-values for the estimates. The definitions for the variables are presented in table $2 . *$ Statistically significant at the five-percent level. Only the coefficients for 54 artists with statistically significant impact on prices are presented. These coefficients may be interpreted as the percent of premia or discounts associated with artists. 
$\exp (3.83+2.6855)=\$ 678,570 .^{7}$ A typical painting by Gris with a coefficient of 1.4678 is $\exp (3.83+1.4678)=\$ 200,337$.

Some of these variables shed light upon the auction process. Other things being equal, paintings sold at auctions held on a day following a previous auction sell for a $7 \%$ discount. Art prices also appear to vary by the month in which the auctions are held. Most auctions are held in November, February, or May. Prices in the May and November auctions are substantially higher than those in February.

The hedonic equation substantially reduces the unexplained variance of the art price series. The residual variance from the hedonic equation is one-tenth the variance of the $\log$ of unadjusted art prices, $\ln P_{i}$. Better estimates of $P_{i}$ result in improved estimation of the time series properties of $V_{t}$ in sections III.D, and in IV of the paper.

\section{Time-Series Behavior of the Art-Price Index, $\ln V_{t}$}

The observations for all paintings sold at auctions held within 28 days of one another are combined into a single observation whose date is assumed to be the date of the earliest auction held within the 28-day period. The resulting aggregate index $\ln V_{t}$ has 53 observations spanning the period May 1977 to May 1995. The time-intervals between these observations vary from 28 days to 365 days. Art-price index observations are matched by date with the S\&P500 and the TOPIX stock price indices.

Figure 1 presents a log-scaled graphical illustration of the three series. All three series exhibit a general upward drift. The rates of increase of art prices and of the TOPIX index accelerate in the late 1980s. Both series decline in the early 1990s. Note also that the variances of price movements of art and Japanese stock prices increase in the late 1980s as the rate of price increases accelerates.

All three series behave like random walk processes with a drift. This issue is investigated using the augmented Dickey-Fuller (ADF) method; see Dickey and Fuller $(1979,1981)$. The equations estimated are

$$
\Delta Y_{t}=\alpha_{0}+\alpha_{1} Y_{t-1}+\sum_{s=1}^{k} c_{s} \Delta Y_{t-s}+u_{t}
$$

where $Y_{t}$ is the natural logarithm of each of the series in figure $1, \Delta$ is

7. Van Gogh's “Starry Night", sold for $\$ 82,500,000$, is the highest sale price in the sample. 


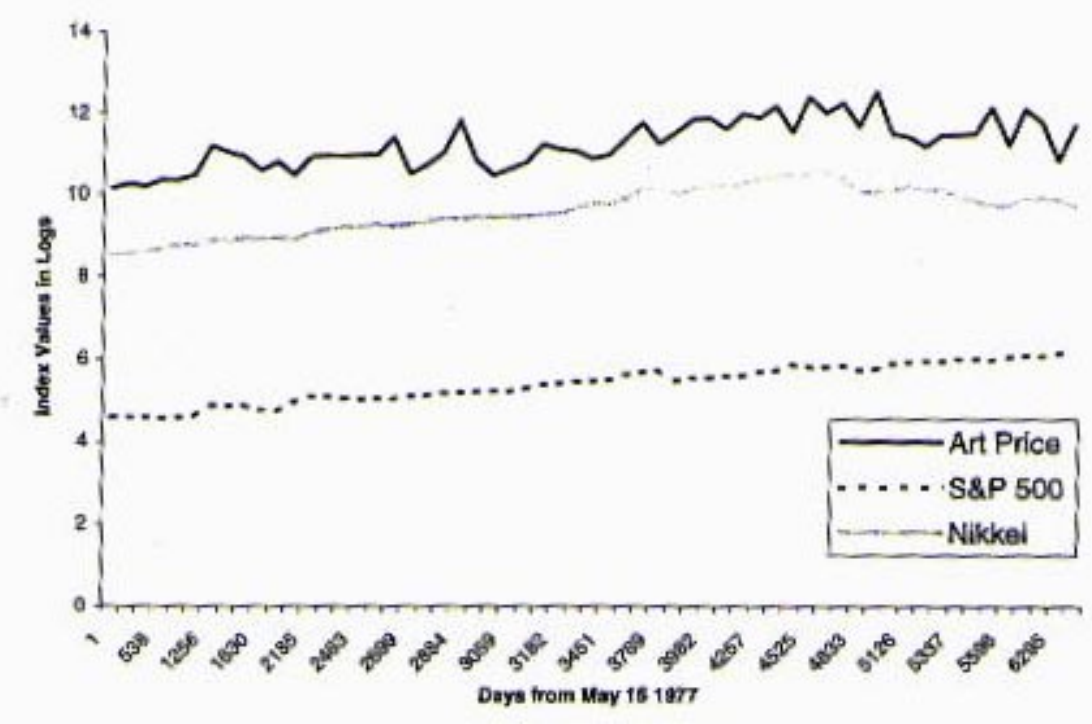

FIGURE 1.-Natural Logarithms of the Art Price, the S\&P500, and the TOPIX Stock Market Indices: May 1977-May 1995.

the first difference operator, $k$ is the number of lag values, and $t$ is time. Note that $Y_{t}=\ln V_{t}$ for the art series, $Y_{t}=\ln S P_{t}$ for the S\&P500 stock market index, and $Y_{t}=\ln T P_{t}$ for the TOPIX index.

Table 4 presents the ADF statistics for testing the null hypothesis of a unit root $\mathrm{H}_{0}: \alpha_{1}=0$ against the alternative hypothesis of a stationary time-series $\mathrm{H}_{1}: \alpha_{1}<0$. The ADF statistics for the log of stock price indices support the null hypothesis of a unit root at the 5\% level of significance. The ADF statistic for the art-price index is inconclusive because of the presence of autocorrelation in the art-price series. Table 4 also presents the $\mathrm{ADF}$ test statistics for the log-returns series, i.e., $R_{V, t}$ $=\Delta \ln V_{t}, R_{U S, t}=\Delta \ln S P_{t}$, and $R_{J P, t}=\Delta \ln T P_{t}{ }^{8}$ All ADF statistics reject the null hypothesis of a unit root in these series. Unlike the log-level series, the log-return series are stationary processes.

Visual inspection of figure 1 indicates the presence of a common long-term price trend in the three series. Cointegration is consistent with the existence of a common, long-term stochastic trend. This article

8. The log-return $R_{t}=\Delta \ln P_{t}=\ln \left(P_{t} / P_{t-1}\right)=\ln \left(1+r_{t}\right) \approx r_{t}$ for small values of the return $r_{t}$. 
TABLE 4. Unit Root Tests for the Log- and Log-Returns of the Art Price-Index, the S\&P500 and TOPIX Stock Market Indices

\begin{tabular}{lccc}
\hline Variables & ADF & F-value & NOBS \\
\hline $\ln V_{t,}$ & $\begin{array}{c}-.34 \\
(-3.69)^{*}\end{array}$ & $6.28^{*}$ & 45 \\
$\ln S P_{t}$ & $\begin{array}{c}-.02 \\
(-.68)\end{array}$ & 4.31 & 45 \\
$\ln N K_{t}$ & $(-1.03$ & 12.15 & 45 \\
& -1.09 & & \\
$R_{V, t}=\Delta \ln V_{t}$ & $(-32.3)^{*}$ & $739.62^{*}$ & 45 \\
$R_{U S, t}=\Delta \ln S P_{t}$ & -1.08 & $283.14^{*}$ & 45 \\
$R_{J P, t}=\Delta \ln N K_{t}$ & $(-34.0)$ & $33.27 *$ & 45 \\
& $(-11.4)^{*}$ & & \\
\hline
\end{tabular}

Notes: The equation tested is $\Delta Y_{t}=\alpha_{0}+\alpha_{1} Y_{t-1}+\sum c_{\mathrm{ts \textrm {s }}} \Delta Y_{t-\mathrm{s}}+u_{\mathrm{t}}$, where $\Delta$ is the first difference operator, $Y_{t}=\ln V_{t}$ for the art price-index, $Y_{t}=\ln S P_{t}$ for the S\&P500 stock index, $Y_{t}=\ln T P_{t}$ for the TOPIX index. NOBS is the number of observations. The ADF statistics test the hypothesis of a unit root (i.e., $\alpha_{1}=0$ ) in each series. Numbers in parentheses are $t$-statistics. The F-value tests the joint hypothesis of a unit root and a drift in the series. The critical value for $\alpha_{1}$ at $5 \%$ for NOBS $=50$ is -3.22 . The null of a unit root cannot be rejected in the cases of $\ln S P_{t}$ and $\ln N K_{t}$. The t-statistic for $\ln V_{t}$ exceeds the critical value. However, the test is inconclusive in the presence of autocorrelation. $\ln V_{t}$ exhibits autocorrelation. In all three cases, the null of a unit root is rejected for the log returns series. Coefficients are approximately -1 , indicating log-returns are stationary. The error term of art log-returns is serially correlated. *Indicates rejection of the null hypothesis of a unit root at the five-percent level of significance.

employs Johansen's (1988) methodology to test for bivariate cointegration of art prices with the U.S. and Japanese stock market prices. Two non-stationary variables are cointegrated if they exhibit a stationary relationship. Tests for cointegration are based upon the following equation:

$$
\Delta X_{t}=\Pi X_{t-p}+\Gamma_{1} \Delta X_{t-1}+\cdots+\Gamma_{p} \Delta X_{t-p}+\mu+\varepsilon_{t}
$$

where $X_{t}$ is the vector of the log-series, $\Delta$ is the first difference operator, $p$ is the maximum number of lags, and $\varepsilon_{t}$ is a vector of i.i.d. error terms with zero mean and variance matrix $\Omega$. A reduced rank of the $\Pi$ matrix 
TABLE 5. Bivariate Tests for Cointegration of Log Values of the Art Price Index with the S\&P 500 and TOPIX Stock Market Indices

\begin{tabular}{|c|c|c|c|}
\hline Null hypothesis & Alternative hypothesis & Statistic & 95\% Critical Value \\
\hline \multicolumn{4}{|c|}{ Number of common stochastic trends for $\ln V_{t}$ and $\ln S P_{t}$} \\
\hline$r=0$ & $r=1$ & 21.72 & 19.22 \\
\hline$r \leq 1$ & $r=2$ & 10.87 & 12.39 \\
\hline \multicolumn{4}{|c|}{ Number of common stochastic trends for $\ln V_{t}$ and $\ln T P_{t}$} \\
\hline$r=0$ & $r=1$ & 29.15 & 19.22 \\
\hline$r \leq 1$ & $r=2$ & 7.24 & 12.39 \\
\hline
\end{tabular}

Notes: Rank tests for $\Pi$ are based upon the test statistic $\lambda_{\max }(r, r+1)=-53 \ln \left(1-\lambda_{r+1}\right)$. Tests on unrestricted intercepts and restricted trends in the VAR, for $T=52$ observations. The null hypothesis of no stochastic trends and the alternative hypothesis of two stochastic trends are rejected. In both cases the test statistic is significant at a 95\% confidence interval for one common stochastic trend (Johansen and Juselius [1990]).

reveals cointegration. $p$ is determined by the Akaike best-fit criterion to be one lag for art-prices and the S\&P500 index and for art-prices and the TOPIX index, but the test statistics do not strongly reject the presence of higher orders of time-dependence. The rank test for $\Pi$ examines the number of characteristic roots that are significantly different from zero. The rank test is based on the following loglikelihood ratio test statistic

$$
\lambda_{\text {max }}(r, r+1)=-T \ln \left(1-\lambda_{r+1}\right),
$$

where $T=53$ is the number of observations in the time series.

Table 5 reports the existence of a common stochastic trend underlying the long-run behavior of art and stock prices. The results of table 5 are consistent with the hypothesis that both markets respond to overall economic trends in the U.S. and Japan as reflected in changing GDP and price levels. An alternative hypothesis is that the art is considered as a substitute for equity securities, with art prices driven by stock prices. The two hypotheses are not exclusive. 


\section{Impact of U.S. and Japanese Stock Markets on Art Prices}

The hypothesis that the stock markets in Japan and the U.S. affect prices of art is tested using the following regression model:

$$
\begin{gathered}
R_{V, t}=\alpha+\beta R_{U S, t}+\gamma R_{J P . t}+\sum_{i=1}^{k} \alpha_{i} R_{V, t-i} \\
+\sum_{i=1}^{p} \beta_{i} R_{U S, t-i}+\sum_{i=1}^{q} \gamma_{i} R_{J P, t-i}+\varepsilon_{t},
\end{gathered}
$$

where $R_{V, t}, R_{U S, t}$, and $R_{J P, t}$, are respectively the returns for the art, the S\&P500, and the TOPIX indices, and $\varepsilon_{t}$ is an error term. The above model is also estimated using a GARCH (generalized autoregressive conditional heteroskadasticity)-type specification for the error term. That is,

$$
\varepsilon_{t} \sim N\left(0, \sigma_{t}^{2}=\delta_{0}+\delta_{1} \varepsilon_{t-1}^{2}+g \sigma_{t-1}^{2}\right) .
$$

Results of the statistical analysis are presented in table 6. Models 1,2, and 3 report OLS specifications of art return equations, and models 4 and 5 report maximum likelihood estimates of art return equations under the assumption that the error term of the equation follows a GARCH process. There is no evidence that short-run art returns are related to the S\&P500 stock returns over the sample period. On the contrary, in all models there is evidence that art log-returns are positively related to contemporaneous TOPIX log-returns. Art returns are negatively related to one-period-lagged TOPIX log-returns and positively related to twoperiod-lagged TOPIX log-returns in model 5. The net effect of changes in the TOPIX index is a one-for-one percentage increase in art prices in models 2,3 , and 5 .

The art return index is strongly heteroskedastic. GARCH maximum likelihood estimation is used in models 4 and 5 to control the variance in art returns. The findings are consistent with the appearance of a causal relationship from Japanese equities to art prices during the latter 
TABLE 6. Regression of Art Index Returns on the S\&P500 and TOPIX Stock Market Index Returns

\begin{tabular}{|c|c|c|c|c|c|}
\hline Variable & Model 1 & Model 2 & Model 3 & Model 4 & Model 5 \\
\hline \multirow[t]{2}{*}{ Intercept } & .0116 & .0066 & .0054 & .0098 & -.0222 \\
\hline & $(.16)$ & $(.10)$ & $(.08)$ & $(.26)$ & $(-.60)$ \\
\hline \multirow[t]{2}{*}{$R_{V, t-1}$} & & -.5740 & -.6959 & -.6535 & -.8229 \\
\hline & & $(-3.91)^{*}$ & $(-4.41)^{*}$ & $(3.79)^{*}$ & $(4.11)^{*}$ \\
\hline \multirow[t]{2}{*}{$R_{V, t-2}$} & & & -.2898 & .1658 & .3009 \\
\hline & & & $(-1.81)$ & (.89) & (1.93) \\
\hline \multirow{2}{*}{$R_{U S, t}$} & -.1711 & .042 & -.0179 & .0154 & .2758 \\
\hline & $(-.22)$ & $(.06)$ & $(-.03)$ & $(.03)$ & $(.37)$ \\
\hline \multirow[t]{2}{*}{$R_{U S, t-1}$} & .8371 & .4528 & .6956 & .4195 & .6758 \\
\hline & $(1.05)$ & $(.62)$ & $(.92)$ & $(.56)$ & $(.74)$ \\
\hline \multirow{2}{*}{$R_{U S, t-2}$} & .1164 & .3468 & .2391 & & -.1555 \\
\hline & $(-.15)$ & $(.48)$ & $(.34)$ & & $(-.16)$ \\
\hline \multirow[t]{2}{*}{$R_{J P, t}$} & 1.5581 & 1.1461 & 1.2814 & 1.0211 & 1.3253 \\
\hline & $(2.41)^{*}$ & $(1.98)^{*}$ & $(2.25)^{*}$ & $(1.52)$ & $(2.01)^{*}$ \\
\hline \multirow[t]{2}{*}{$R_{J P, t-1}$} & -1.7634 & -.5141 & -.6058 & -1.8787 & -2.0638 \\
\hline & $(-2.51)^{*}$ & $(-.73)$ & $(-.88)$ & $(-1.35)$ & $(-2.81)^{*}$ \\
\hline \multirow[t]{2}{*}{$R_{J P, t-2}$} & .3744 & -.5762 & -.2514 & & 1.4652 \\
\hline & $(.55)$ & $(-.878)$ & $(-.38)$ & & $(2.56)^{*}$ \\
\hline \multirow[t]{2}{*}{$\delta_{0}$} & & & & .0984 & .0433 \\
\hline & & & & $(4.32)^{*}$ & $(4.34)^{*}$ \\
\hline \multirow[t]{2}{*}{$\delta_{1}$} & & & & .0315 & \\
\hline & & & & $(.17)$ & \\
\hline \multirow{2}{*}{$g$} & & & & & .5041 \\
\hline & & & & & $(579.4)^{*}$ \\
\hline R-square & .19 & .41 & .46 & .42 & .51 \\
\hline F-value & 2.76 & 4.04 & 4.15 & & \\
\hline AIC & & & & 46.04 & 41.96 \\
\hline DW & 2.90 & 2.09 & 1.89 & & \\
\hline NOBS & 51 & 51 & 51 & 52 & 51 \\
\hline
\end{tabular}

Notes: Models 1-3 report OLS results with lagged values of log art prices. Models 4-5 report maximum likelihood estimates of art price returns controlling for autocorrelation and heteroskedasticity.

half of the 1980s. Controlling for heteroskedasticity does not alter the relationships between art price returns and stock market returns found in the OLS specifications.

Findings presented in tables 5 and 6 provide evidence that the forces that propel international equity markets also drive the art market. This finding reinforces perceptions of art market participants during the 1980s. The net short-term effect of Japanese stock prices in Table 6 
appears to be positive - concurrent Japanese market developments have a positive influence, lagged one auction date they are negative, and lagged two auction dates in equation 5, positive. The net effect appears to be proportional - a one-percent change in Japanese stock prices is associated with a one-percent change in art prices in equations 2 through 5.

\section{Summary and Concluding Remarks}

Art prices at auctions held by Sotheby's and Christies in New York City from 1977 to 1995, adjusted for varying physical characteristics and provenance and for auction market characteristics, were significantly related to stock markets over the same period. The returns series were stationary over the sample period. Art-price returns exhibited first-order autocorrelation and heteroskedasticity.

Tests using a first-order vector autoregressive model with an errorcorrection term revealed that art and stock log-prices shared a single, common, long-term trend. While this article did not identify the underlying trend, one could hypothesize that it was not nominal price levels, as stock price increased in the face of a secular decline in inflation over the sample period. More likely, the income elasticity for art was positive, and art prices reflected the increases in wealth and associated income flows that were revealed in growing stock prices.

Price volatility increased in both the art market and Japanese stock markets during the late 1980s. Over the same period, Japanese stock prices climbed sharply and the dollar fell versus the yen, reducing the cost of foreign assets to Japanese Investors. The combination of high Japanese security prices and low yen cost of art, ceteris paribus, made western art an attractive asset to Japanese investors. The quotes reported at the beginning of this paper provide anecdotal evidence that market participants believed that Japanese investors did take advantage of this opportunity, in the process applying unanticipated buying pressure to the market for modern and impressionist paintings. Certainly sellers understood the potential buying power of Japanese investors - major art auction houses opened Far Eastern sales offices in the second half of the 1980s.

As new market participants reduced the capitalization rates required 
to hold paintings, they introduced new information into the art market. In essence, art market participants argued that demand for modern and impressionist art from Japanese investors was an unexpected phenomenon that caused a temporary upward shift in art prices and led to a sharp increase in price volatility. Art prices subsequently accompanied Japanese equities in a decline that lasted through the end of the sample period. The decline in Japanese equities reflected the country's banking crisis. Over this same period, the U.S. stock market had followed a general uptrend.

Statistical support for the above explanation of the short-term behavior of art and Japanese equity markets was also provided. The short-term relationships between art returns (log-changes) and stock returns were evaluated using OLS and ARCH-GARCH equations. The results provided consistent evidence that art returns and Japanese stock market returns were contemporaneously correlated over the sample period. Over the sample period, log-changes in the TOPIX index were associated with proportional changes in log art prices. Miller, Sklartz, and Ordway (1988) provide corroborating evidence from another realasset market during the same period.

This article provides evidence that art prices and U.S. and Japanese equities responded to a common long-term factor during the 1970s and 1980s. The article finds evidence also that Japanese stock prices influenced the short-term behavior of art prices. This evidence supports the hypothesis that investors view art as a positive complement in portfolios containing international equity securities. Art prices respond, like international equities, to expected returns and systematic risk. Equation 4 indicates that, unlike equities, art returns display first-order autocorrelation. Serial correlation does not indicate that investors can make above-normal profits buying and selling art, however, because the art market is less liquid than stock markets. Art investors incur large transaction costs when buying and selling paintings.

Results of the article show that, despite the importance of aesthetic concerns that are specific to individual investors and that dominate a collector's demand for individual paintings, the art market is able to make consistent determinations of market value across many paintings and over time. Moreover, the article demonstrates that art prices are determined in the same international financial market that prices more prosaic equity securities. The article provides analytic methods that can 
be utilized by art investors, museums, auction houses, and other art market participants to value paintings relative to each other and to other assets over time. Given the large body of historical data on art transactions, market participants can use the techniques employed here to construct models that cover longer time periods and include more observations. These models will be able to accurately evaluate the market potentials of individual paintings when they are employed across a large number of transactions. Using these empirical models, investors can develop improved investment strategies for art collection and disposition. Finally, by bringing yet another real asset under the rubric of systematic risk and expected return valuation, the paper further demonstrates the broad power of the pricing models used in modern finance to explain the behavior of asset returns.

\section{References}

Anderson, R. 1974. Paintings and investment. Economic Inquiry 12:13-26.

Baumol, W. 1986. Unnatural value or art investment as floating crap game. American Finance Association Papers and Proceedings 76:1-14.

Case, K. and Shiller, R. 1989. The efficiency of the market for single-market homes. American Economic Review 79 (March):125-137.

Chin, K., Henderschott, P., and Sanders, A. 1990. Risk and return on real estate: Evidence from equity REITS. AREUEA 18:431-451.

Chow, G. 1960. Tests of equality between sets of coefficients in two linear regressions. Econometrica 28:59-605.

Dickey, D. A., and Fuller, W. A. June 1979. Distribution of the estimates for autoregressive time series with unit root. Journal of the American Statistical Association 74: 427-32.

Dickey, D. A. and Fuller, W. A. July 1981. Likelihood ratio statistics for autoregressive time series with a unit root. Econometrica 49: 1057-72.

Frey, B. and Pommerehne, W. 1989. Art investment: An empirical inquiry. Southern Economic Journal 56:396-408.

Goetzmann, W. 1993. Accounting for taste: Art and the financial markets over three centuries. American Economic Review 83 (December):1370-1376.

Heilbrun, J. and Gray, C. 1993. The Economics of Art and Culture: An American Perspective. Cambridge: Cambridge Press.

Johansen, S. 1988. Statistical analysis of cointegration vectors, Journal of Economic Dynamics and Control 12(2/3): 231-54.

Johansen, S and Juselius, K. 1990. Maximum likelihood estimation and 
inference on cointegration with applications to the demand for money. Oxford Bulletin of Economics and Statistics 52:169-210.

Ibbotson, R. and Siegal, L. 1989. Real estate returns: Comparisons with other assets. AREUEA 17:219-242.

Mahar, M. 1987. What price art? In an overheated auction market, it's whatever you'll pay. Barrons (June 29):6-7 and 30-32.

Mark, J. 1983. An empirical examination of the stability of housing price equations over time. AREUEA 11:397-415.

Matsumoto, K., Andoh, S, and Hoban, J. 1994. Rates of return on art objects, the Fisher hypothesis, and inflationary expectations. Financial Review 29: 497-519.

Miller, N., Sklartz, M. and Ordway, N. 1988. Japanese purchases, exchange rates, and speculation in residential real estate markets. Journal of Real Estate Research 3:39-50.

Pesando, J. 1993. Art as an investment: The market for modern prints. American Economic Review 83 (December):1075-1089.

Ross, S. 1989. Information and Volatility: The no-arbitrage Martingale approach to timing and resolution irrelevancy. Journal of Finance 44:1-18.

Ross, S. and Zisler, R. 1991. Risk and return in real estate. Journal of Real Estate Economics and Finance 2:175-190.

Stein, J. 1977. The monetary appreciation of paintings. Journal of Political Economy 85:1021-1035.

Taylor, W. 1992. The estimation of quality-adjusted auction returns with varying transaction intervals. Journal of Financial and Quantitative Analysis 27:131-143.

Throsby, D. 1994. The production and consumption of the arts: A view of cultural economics. Journal of Economic Literature 32:1-29. 